\title{
THE ROLE \\ OF ORGANIZATIONAL COMMITMENT AND \\ PROCEDURAL JUSTICE IN MODERATING \\ THE RELATIONSHIP BETWEEN \\ BUDGETARY PARTICIPATION AND \\ MANAGERIAL PERFORMANCE
}

Etty Murwaningsari*

The objective of this research is to identify the role of organizational commitment and procedural justice in moderating the relationship between budgetary participation and managerial performance.

This research utilizes the mail survey method to collect primary data from September 2007 to mid-November 2007 by sending questionnaire forms to corporate managers involved in the budgeting process.

The empirical result of this research indicates that budget participation has a positive and significant influence on managerial performance. The subsequent test finds that organizational commitment can strengthen the relation between budget participation and managerial performance. The last test shows that procedures have no influence on the relationship between budget participation and managerial performance.

Keywords: budgetary participation; organizational commitment; managerial performance; procedural justice

*The author wrote this article while pursuing the doctoral degree in accounting from PIA University of Indonesia, Jakarta. 
Gadjah Mada International Journal of Business, May - August 2008, Vol. 10, No. 2

\section{Introduction}

Budget is one of the important components which a firm has. An organization needs budget to translate all the organization's strategies into short-term and long-term plans and objectives (Hansen and Mowen 1997).

A budgeting process is an important activity involving all managerial levels from top managers to lower ones whose roles are preparing and evaluating various alternatives of the budgetary objectives, and that budget is always used as the best measure of managers' performance (Kren 1992).

One function of budgetary participation is that it is used as a medium of communications between higher and lower managers to discuss not only budgetary issues but also other related issues (Brownell and Hirst 1998). The effects of participative budgeting on managerial performance have been a topic of interest and are widely examined in the studies of management accounting (Lukka 1998). Brownel suggests two reasons: (a) budgetary participation is viewed as a managerial approach able to improve the performance of an organization's members, and (b) many studies testing the relationship between budgetary participation and managerial performance showed mixed results.

Many studies in management accounting are concerned with budgetary participation issues (Brownell 1981). This concern has been driven by a view that participative budgeting has a significant consequence to the behavior of an organization's members (Murray 1990). Lower managers/ management whose aspirations are taken into account and affect the budgeting scheme will show greater responsibility and moral consequence to perform better in compliance with the budgetary targets (Supomo 1998).

Strong organizational commitment; as a form of acceptance of organizational objectives; and a willingness to make efforts for the organization's best interest increase managerial performance (Nouri and Parker 1998).

Procedural justice is associated with the perception of employees lower down the hierarchy of all processes used by their superiors to evaluate their performance and as a mean of communicating feedbacks and determining the reward they deserve to receive, such as promotion or a raise (McFarlin and Sweeney 1992). Tang and Sarfield-Baldwin (1996) suggest that if managers apply corporate rules equally and consistently to all employees and reward them due to their performance and achievement without any personal biases, employees will perceive procedural justice positively.

Motivated by previous studies, the study reaffirms whether budgetary participation has significant effects on managerial performance (Brownell 1982). Moreover, it also tests whether the organizational commitment variable (Nouri and Parker 1996) and the procedural justice variable (Lou and 
Murwaningsari-The Role of Organizational Commitment and Procedural Justice in Moderating the Relationship ...

Lim 2002) may moderate the relationship between budgetary participation and managerial performance. Based on the aforementioned suggestions, the objective of this study is to know:

1. The budgetary participation increases managerial performance.

2. The degree of correlation between budgetary participation and organizational commitment corresponds to increased managerial performance.

3. The degree of correlation between budgetary participation and procedural justice corresponds to increased managerial performance.

\section{Review of Relevant Studies}

\section{The Basic Theory of Budgetary Studies}

Shield and Shield (1998) examine studies on budgetary participation and infer that nearly all budgetary studies are based on the following theories:

a. Economic Theory. It is based on the assumption that budget provides a fair ground to select and share information among those involved in a budgeting process. The economic theory suggests that individuals engaged in a budgeting process are motivated by two stimulants: (1) information sharing and (2) task coordination.

b. Psychological Theory. It suggests that budgetary participation provides information sharing between top and lower managers/manage-
ment(Hopwood 1976). Psychological theory argues that two reasons make budgetary participation necessary (Hopwood 1976): (1) the involvement of top and lower managers in budgetary participation controls of asymmetric information and task uncertainty, (2) budgetary participation allows individuals to have reduced tasks and job satisfaction, and these in turn lead to reduced budgetary gaps. Psychological theory introduces three main factors in the top and lower managers' involvement in budgetary participation (Locke and Latham 1990), namely (1) value attainment; (2) cognition; and (3) motivation.

c. Sociological Theory. Shield and Shield (1998) suggest that psychological theory assumes more uncertain organizational external environments, indicated by increased differences in an organization's units in terms of number and type. Consequently, an increased budgetary participation is required to coordinate the units' activities and align all activities in the organization. Sociological theory is related to such organizational contexts as environmental uncertainty, organizational structures, and functional differentiation that affect budgetary participation. Sociological theory on which budgetary participation based on the organizational contingency theory (Hopwood 1976). 
Gadjah Mada International Journal of Business, May - August 2008, Vol. 10, No. 2

\section{Contingency Approach}

Contingency theory predicts that an organization's external environment is bound to many uncertainties. Contingency theory has a principle that there is no a single type of organizational structure nor management system which is more efficient and effective for all organizations. Therefore, a different ecological context should consider main contextual factors such as an organization's size, technology, and environment (Lawrence and Lorsch 1967)

One function of management accounting system is to provide budget that helps managers control their activities and lessen environment uncertainties to achieve the organizational objectives (Gordon and Millar 1976). A management accounting system is generally a contingency approach of a conditional factor as a variable that moderates a relationship. Brownell (1982) examines several studies and finds the effects of conditional factors that serve as moderating variables to the relationship between independent and dependent variables. The conditional factors may be categorized into 4 variables, i.e. cultural, organizational, interpersonal, and individual. Govindarajan (1986) suggests that it is necessary to use the contingency approach to identify various conditions leading to more effective participative budgeting. Researchers have documented that the effectiveness of budgetary participation depends on the organizationally contextual factors and the characteristics of employees' psychology (Brownell 1981). In this study, the author used the contingency theory to evaluate the relationship between budgetary participation and managerial performance. The author choose the contextual of the contingency factors, i.e. corporate managers' Procedural Justice and Organizational Commitment.

\section{The Concept of Fit}

Some approaches can be used to define the concept of fit in the literature of strategies, i.e. selection, interaction, and system approaches (Van de Vend and Drazin 1985). The selection approach does not address the performance implications of a system (that is, the study's main focus is to examine the characteristics of organizations that implement certain systems). The interaction approach, however, primarily examines conditional factors that determine or affect the impact of a (participative) system on performance. Finally, the system approach defines fit as the degree of consistence; that is, the internal consistence of many contingencies, structures, and performance characteristics (Van de Ven and Drazin 1985). Thus, a system's effectiveness is determined by the extent to which conditional factors meet the system's conditional prerequisites. This approach allows researchers to study the effects of conditional factors in the relationship between a (participative) system and performance (Govindarajan 1986). This study extends those studies in which it 
Murwaningsari-The Role of Organizational Commitment and Procedural Justice in Moderating the Relationship ...

Figure 1. The Framework

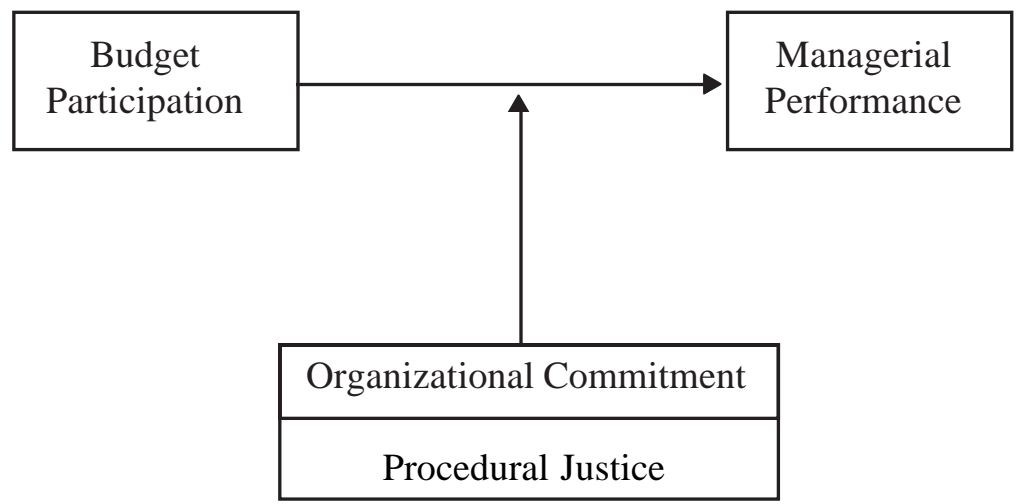

tests the effects or the degree of consistence (fit) of the conditional factors, i.e. Procedural Justice and Organizational Commitment, on the effects of budgetary participation on managerial performance.

\section{The Development of the Hypothesis}

\section{Budgetary Participation and Managerial Performance}

Budgetary participation is expected to increase managers' performance; that is, when an objective has been designed and approved in a participatory way, employees will internalize the defined objective and they will have personal responsibility to achieve it due to their involvement in the budgeting process (Milani 1975). Greenberg and Folger (1983) argue that budgetary participation increases performance because (i) it allows lower management to communicate their needs to the upper or top management and (ii) it allows lower management to select amongst available options, and this selection exercises generate commitment as a form of responsibility for what they have chosen.

The studies of budgetary participation on managerial performance have shown mixed results. Some studies indicate evidence that budgetary participation has a strong positive effect on managerial performance (Argyris 1952). Other studies have also reported positive results (Merchant 1981; Brownell and Hirst 1998). Bryan and Locke (1967), however, find that budgetary participation has a negative effect on performance. Milani (1975) and Brownell and Hirst (1998) find that budgetary participation has an insignificant effect on managerial performance. Brownell and McInnes (1986), who investigated 224 respondents of mid-level managers in manufacturing firms, also find that high participation in budgeting increases managerial performance. 
The inconsistent results have led some Indonesian researchers to investigate the variables in question. Indriantoro (1993), for example, finds a significant and positive association between budgetary participation and managerial performance. Riyanto (1997) and Supomo (1998) find that budgetary participation has an insignificant effect on managerial performance. Poerwati (2002), in a study involving 700 managers of manufacturing firms listed in the Jakarta Stock Exchange and appeared in the Indonesian Capital Market Directory, finds that budgetary participation has an indirect effect on managerial performance. Hariyanti and Nasir (2002), in a sample of 900 managers and heads of divisions comparable to managers in rank who chair functional departments in manufacturing firms in Indonesia, find a positive association between budgetary participation and managerial performance. Accordingly, the following hypothesis is developed:

$H_{1}$ : Budgetary participation has a positive effect on managerial performance.

\section{Organizational Commitment Moderates Budgetary Participation and Managerial Performance}

Govindarajan (1986) reconciles the mixed results of those studies using the contingency approach that evaluates various conditional factors affecting the effectiveness of budgeting participation on managerial per- formance. Brownell(1982) categorizes the conditional factors (moderating variables) into four groups of variables, i.e. cultural, organizational, cross-individual, and individual. The contingency approach is adopted in this study to evaluate the effects of budgeting participation on managerial performance.

In Wiener (1982), organizational commitment is defined as an individual's force to support the organization's success in compliance with the stipulated objectives and prioritize the organization's interests. Strong organizational commitment motivates individuals to make efforts to achieve the organization's objectives and goals (Angel and Perry 1981). Brownell and Hirst (1986) categorizes the conditional factors (the moderating variables) into four groups of variables: cultural, organizational, cross-individual, and individual.

\section{The Relationship between Budgetary Participation and Organizational Commitment}

Nouri and Parker (1998) use a sample of 135 managers of U.S. multinational corporations in the chemical industry. The study concludes that there is a positive association between effective organizational commitment and managerial performance. High organizational commitment is a form of acceptance to the organization's objectives and goal and willingness to make organizational efforts which increase managerial performance. Bud- 
Murwaningsari-The Role of Organizational Commitment and Procedural Justice in Moderating the Relationship ...

getary participation is not only associated with budgetary targets but it also includes acceptance and trust in the organization's values and objectives and goal; thus, budgeting participation has an indirect effect on organizational commitment.

Hariyanti and Nasir (2002), who use a sample of 900 managers or heads of divisions comparable to managers in capacity that manage functional departments in Indonesian manufacturing companies, find a positive correlation between budgetary participation and organizational commitment. They also find a positive relationship between organizational commitment and managerial performance.

\section{The Relationship between Organizational Commitment and Managerial Performance}

Nouri and Parker (1998) suggest that strong organizational commitment as a form of acceptance of the organization's objectives and goal and willingness to make efforts in the organizations best interest increases managerial performance. Sumarno (2005), using a sample of 90 managers responsible for budgeting of the main banks' branch offices in Jakarta, finds that organizational commitment has positive significant effects on the relationship between budgetary participation and managerial performance. Based on the findings that the relationship between budgetary participation and managerial performance in which a commitment variable serves as a moderating variable, the following hypothesis is suggested:

$\mathrm{H}_{2}$ : Organizational commitment has positively significant effects on the relationship between budgetary participation and managerial performance.

\section{Procedural Justice Moderates Budgetary Participation and Managerial Performance}

While some authors believe that budgetary participation is related to procedural justice (Tibaut and Walker 1975), budgetary participation and procedural justice are actually different in nature. Procedural justice bears a broader notion than budgetary participation and is affected by many factors.

\section{The Relationship between \\ Procedural Justice and Managerial Performance}

Studies of the effects of procedural justice on managerial performance have shown inconsistent results. Some studies argue that they are positively correlated (Earley and Lind 1987), while other studies suggest that they are negatively correlated (Kanfer et al. 1987). The conflicting results may be attributed to complex and indirect relationship between procedural justice and managerial performance (Lind and Tyler 1988).

The indirect relationship between the perceived procedural justice and managerial performance has been previously examined by Lau and Lim 
Gadjah Mada International Journal of Business, May - August 2008, Vol. 10, No. 2

(2002) that finds a correlation between procedural justice and managerial performance through an intervening variable, i.e. participative budgeting or budgetary participation. Lau and Lim (2002) extend previous studies by Lindquist (1995) and Libby (2001). Wasisto and Solihin (2004), who replicate the findings of Lau and Lim (2002) by using a sample of 229 managers of manufacturing companies listed in the Jakarta Stock Exchange and appeared in the 2002 Indonesian Capital Market Directory; find a significant relationship between procedural justice and managerial performance. The relationship is, however, indirect as it is fully mediated by budgetary participation.

\section{The Relationship between Procedural Justice and Budgetary Participation}

Procedural justice may be well regarded as the antecedent of budgetary participation. Based on the premise of the extent in which an organization weighs on maintaining procedural justice, this leads upper management to consider the lower management's participation in the budgeting process (Friedland et al. 1973).

As equality or justice is a key factor in a procedural selection, and as a participation-involving procedure promotes fairness and equality, it is very likely that an organization committed to maintaining high procedural justice tends to select a participative procedure (Thibaut and Walker 1975).

This leads to a hypothesis of the relationship between the three variables:

$H_{3}$ : Procedural justice has positively significant effects on the relationship between budgetary participation and managerial performance.

\section{The Research Methodology}

\section{Variables and Measurement}

\section{The Dependent Variable}

This study uses Managerial Performance as a dependent variable. This dependence variable includes, amongst others: planning, investigation, coordination, supervision, staff arrangement, negotiation, and representation (Mahoney et al. 1963). Following the previous studies, the author use an instrument developed by Milani(1975) to measure the budgetary participation variable. Each of the survey's participants was asked to respond to six questions to measure the degree of participation and the perceived effects on them as well as their contribution to the budgeting process. Responses were given by choosing points of the questions, ranging from 1 (all budgeting processes) to 7 (no budgeting process). The answers to the questions are arranged using the Likert scale from 1 to 7 . The instrument has been well tested and used by the previous researchers (authors) such as Brownell 
Murwaningsari-The Role of Organizational Commitment and Procedural Justice in Moderating the Relationship ...

(1982b), Brownell and McInnes (1986), Indriantoro (1993), and Gul et al. (1995). Some Indonesian researchers have also used this instrument, for example, Supomo (1998), Poerwati (2002), Hariyanti and Nasir (2002), Wasisto and Solihin (2004), and Sumarno (2005).

\section{The Independent Variable}

The author uses the budgetary participation as the independent variable in the study, indicating individuals' involvement and influence in the budgeting process (Brownell 1982); and the "self rating" instrument developed by Mahoney et al. (1963) to measure managerial performance. Author use self-rating as (1) it provides anonymous assessment, and (2) specifically, the upper management provides less and subjective information (Heneman 1974). Mahoney's measure has two advantages, i.e. (1) independent assessment of the measure's reliability and validity has generated satisfactory results in other studies, (2) the measure explicitly reveals the multidimensional characteristics of managerial performance (Govindarajan 1986 in Lau and Lim 2002). Each of the respondents was asked to measure his or her performance. The answers to the questions were arranged using the Likert scale from 1 to 9 . The value of the scale indicates the value of the score of each question. The instrument has been proven robust and has been used in previous studies such as in Brownell (1982), Brownell and McInnes (1986), and Indriantoro
(1993). It has also been used in Poerwati (2002), Hariyanti and Nasir (2002), Wasisto and Solihin (2004), and Sumarno (2005).

\section{The Moderating Variable}

The moderating variable is an independent variable included in the model as it has the contingency effects of the dependent and independent variables. In the study, the moderating variable includes:

a. The organizational commitment, which is defined as individual's internal drive to contribute to the organization's success and to make efforts in the organization's best interest (Wiener 1982).

The organizational commitment is measured using the interval scale. The list of questions developed by Mowday (1979) for the organizational commitment is used. The answers to the questions were arranged using the Likert scale from 1 (highly disagree) to 7 (highly agree). The scale's value indicates the score value of each question. The Cronbach's alpha $>0.6$ score indicates the acceptance of the instrument's reliability used in the study. The reasonable degree of the measure's validity/robustness and reliability has been reported by previous authors (Nouri and Parker 1996).

b. The procedural justice, which is related to the lower management's perception of all the processes implemented by the upper management to evaluate their performance, 
Gadjah Mada International Journal of Business, May - August 2008, Vol. 10, No. 2

as a mean to communicate performance feedback and determine appropriate rewards such as promotion or a raise (McFarlin and Sweeny 1992).

The procedural justice is measured using the four-item interval scale instrument used by Lau and Lim (2002) and Wasisto and Solihin (2004) to measure the lower management's perception of the procedural justice. The answers to the questions were arranged using the Likert scale from 1 to 5 . The respondents answered the questions by choosing scales from 1 (highly unfair), 2 (unfair), 3 (neutral), 4 (fair), and 5 (highly fair). The scale's value indicates the score's value of each question. The Cronbach's alpha $>0.6$ score suggests the reasonableness of the instrument used in the study.

\section{The Data Collecting Technique}

The author used the mail survey method to collect primary data from September 2007 to mid-November 2007 by sending forms of questionnaire to corporate managers involved in the budgeting process. Looking at the results of the previous studies in Indonesia, especially those using primary data, the response rate ranges from 10 percent to 20 percent (Hariyanti and Nasir 2002).

a. The Robustness Test. The robustness test is used to show how real a test measures what should be measured. The test is conducted by finding the correlation of each indicator to its total score using the Pearson Correlation test. It is robust when the correlation is significant at the level of $<0.05$.

b. The Reliability Test. The test is used to measure the internal consistence of a construct's indicators, in that how far each of the indicators indicate a construct. The reliability test is conducted by calculating the magnitude of the Cronbach's coefficient alpha of each instrument in a variable, that is, a positive relationship across items or questions. If alpha $>0.6$, the data are thus reliable.

Table 1. The Process of Distributing and Receiving the Questionnaire

\begin{tabular}{|c|c|c|}
\hline Definition & Amount & Percentage \\
\hline Questionnaire distributed & 150 & $100 \%$ \\
\hline Questionnaire received & 35 & $23 \%$ \\
\hline Unusable questionnaire & 3 & $2 \%$ \\
\hline Usable questionnaire & 32 & $21 \%$ \\
\hline
\end{tabular}


Murwaningsari-The Role of Organizational Commitment and Procedural Justice in Moderating the Relationship ...

\section{The Normality Test}

The normality test is used to test whether the dependent and independent variables have normal distribution in a regression model. The author used the Kolmogorov-Smirnov data normality test in the study. The test criteria suggest that if it is significant of $>0.05$, then $\mathrm{H}_{0}$ applies - indicating that the data distribution is normal and otherwise.

\section{The Hypothesis Test}

a. An analysis regression model to answer the Hypothesis 1. In the Hypothesis Test 2, the Moderate Regression Analysis (MRA) is used to determine the effects of interactions. Mathematically, the Equation 1 is as follows:

$$
\mathrm{Y}=\beta \mathrm{o}+\beta_{1} \mathrm{X}_{1}+\varepsilon
$$

The Equation 2 is shown by the Equations (2a) dan (2b)

$$
\begin{array}{r}
Y=\beta o+\beta_{1} X_{1}+\beta_{2} X_{2}+\varepsilon \ldots . .(2 a) \\
Y= \\
\beta o+\beta_{1} X_{1}+\beta_{2} X_{2}+\beta_{3} X_{1} X_{2}+ \\
\varepsilon \ldots \ldots \ldots \ldots \ldots \ldots \ldots \ldots \ldots \ldots \ldots \ldots \ldots \ldots \ldots \ldots \ldots \ldots \ldots \ldots \ldots \ldots \ldots \ldots \ldots \ldots \ldots
\end{array}
$$

The hypothesis 3 is shown by the Equations (3a) dan (3b)

$$
\begin{aligned}
Y= & \beta o+\beta_{1} X_{1}+\beta_{3} X_{3}+\varepsilon \ldots \text { (3a) } \\
Y= & \beta o+\beta_{1} X_{1}+\beta_{3} X_{3}+\beta_{4} X_{1} X_{3}+ \\
& \varepsilon \ldots \ldots \ldots \ldots \ldots \ldots \ldots \ldots \ldots \ldots \ldots \ldots \ldots \ldots \ldots \ldots \ldots \ldots \ldots \ldots \ldots \ldots \ldots
\end{aligned}
$$

Where:

$\mathrm{Y}=$ dependent variable $=$ Managerial Performance;

$\beta_{1}, \beta_{2}, \beta_{3}$, and $\beta_{4}=$ regression coefficients;

$\mathrm{X}_{1}=$ independent variable= Budgetary Participation;

$\mathrm{X}_{2}$, and $\mathrm{X}_{3}=$ moderating variable

$X_{2}$ : Organizational Commitment;

$X_{3}$ : Procedural Justice;

$X_{1} X_{2}=$ the interactions of $X_{1}$ and $X_{2}$;

$\mathrm{X}_{1} \mathrm{X}_{3}=$ the interactions of $\mathrm{X}_{1}$ and $\mathrm{X}_{3}$;

$\varepsilon=$ error

b. The Determination Coefficient. The author used the coefficient $\left(\mathrm{R}^{2}\right)$ to find out how good the dependent variable is in explaining the independent variable. The measurement explains the Goodness of Fit of the model in which the closer it is to 1 , then the model has more Goodness of Fit; but if it is closer to 0 , then the model has less Goodness of Fit.

c. The t-test (the Individual test) is a regression coefficient test of each of the dependent over the independent variables to gauge the effects of one on the other.

$\mathrm{H}_{0}=\beta_{1}=0$ has no effect if $p$-value $<(\alpha=0,05)$, then $\mathrm{H}_{0}$ is unacceptable. 


\section{Analyses and Results}

\section{The Descriptive Statistics}

The author observed the descriptive statistics based on the means and standard deviations. The Table 2 is the results of four variables used in the study.

The Table 2 shows that the respondents' answer to the Budgetary Participation variable has a mean of 4.4900. The scale 1 for this variable suggests high participation. Therefore, the mean of 4.4900 indicates that the sample corporate managers are quite participative and involved in the budgeting process.

The Managerial Performance variable has a mean of 5.8094. Dividing performance into three categories, the mean value suggests the managers of the manufacturing companies have average managerial performance. The observed managerial activities include planning, investigation, coordination, supervision, staff arrangement, negotiation, and representation.
The Organizational Commitment variable has a mean of 4.6919, indicating that the managers are quite committed to the organizations where they work. The managers show that they are proud, happy, and they care for their organizations as indicated by their willingmess to work harder, their acceptance of any jobs assigned, and tell their friends and people in general about their organizations.

The Table 2 also provides information about the Procedural Justice variable that has a mean of 3.6250 . Using Likert scale point 5, it suggests that managers find procedural justice in their workplaces. The procedures used by the organizations include promotion and a raise, employee performance evaluation as well as performance feedbacks.

The standard deviation values suggest a variation (heterogeneity) of data distribution of each variable. The standard deviation values of the four variables used in the study indicate varied data distribution.

Table 2. The Descriptive Statistics of the Variables Used in the Study

\begin{tabular}{|c|c|c|c|c|}
\hline Variable & $\begin{array}{l}\text { Number of } \\
\text { Indicator }\end{array}$ & Scale & Mean & $\begin{array}{l}\text { Deviation } \\
\text { Standard }\end{array}$ \\
\hline Budgetary Participation & 6 & $1-7$ & 4,4900 & 0,70442 \\
\hline Managerial Performance & 9 & $1-9$ & 5,8094 & 0,95898 \\
\hline Organizational Commitment & 9 & $1-7$ & 4,6919 & 1,09442 \\
\hline Procedural Justice & 4 & $1-5$ & 3,6250 & 0,51977 \\
\hline
\end{tabular}


Murwaningsari-The Role of Organizational Commitment and Procedural Justice in Moderating the Relationship ...

\section{The Data Quality Test and the Classical Test}

The Robustness Test. The results of the robustness test for each of the construct are as follow:

- The results of the validity test show that there are six indicators to measure the Budgetary Participation construct whose $p$-value is less than 0.05 , indicating that $\mathrm{PA}_{1}-\mathrm{PA}_{6}$ indicators are robust. The correlation coefficients range from 0.405 0.775 .

- There are nine indicators that can be used to measure the Managerial Performance construct whose $p$-value is less than 0.05. This indicates that $\mathrm{KM}_{1}-\mathrm{KM}_{9}$ are robust. The correlation coefficients range from 0.510 0.950 .

- The nine indicators used to measure the Organizational Commitment construct show $p$-value that is less than 0.05. This indicates that $\mathrm{KO}_{1}-\mathrm{KO}_{9}$ are robust. The correlation coefficient is at least 0.547 and 0.934 at the most.
- The robustness test for the Procedural Justice construct indicates that four indicators have $p$-value less than 0.05. This suggests that $K P_{1}-K_{4}$ are robust. The minimal correlation coefficient is of 0.694 and the maximal is 0.831 .

The Reliability Test. The results of the reliability test for the four constructs in the study are shown in the Table 3.

The Cronbach's alpha coefficient in the four constructs meets the reliability criteria, that is, it is more than 0.60 . Therefore, it can be concluded that the data used (that is, the respondents' answers to each of the constructs) are reliable.

The Normality Test. The hypotheses of the normality test can be defined as: $H_{0}$ : The data are derived from the normal population.

$H_{a}$ : The data are derived from the abnormal population.

The decision taking: If sig. $<0.05$, then $\mathrm{H}_{0}$ is unacceptable, and otherwise.

Table 3. The Realiability Test Results

\begin{tabular}{|c|c|c|}
\hline Construct & $\begin{array}{l}\text { Number of } \\
\text { Items }\end{array}$ & $\begin{array}{c}\text { Cronbach's } \\
\text { Coefficient Alpha }\end{array}$ \\
\hline Budgetary Participation & 6 & 0,639 \\
\hline Managerial Performance & 9 & 0,822 \\
\hline Organizational Commitment & 9 & 0,928 \\
\hline Procedural Justice & 4 & 0,758 \\
\hline
\end{tabular}


Gadjah Mada International Journal of Business, May - August 2008, Vol. 10, No. 2

Table 4. The Normality Test for Each Variable

\begin{tabular}{|c|c|c|}
\hline Variable & Sig. & Decision on $\mathbf{H}_{0}$ \\
\hline Budgetary Participation & 0,177 & $\mathrm{H}_{0}$ failed and rejected \\
\hline Managerial Performance & 0,807 & $\mathrm{H}_{0}$ failed and rejected \\
\hline Organizational Commitment & 0,628 & $\mathrm{H}_{0}$ failed and rejected \\
\hline Procedural Justice & 0,090 & $\mathrm{H}_{0}$ failed and rejected \\
\hline
\end{tabular}

Table 5. The Results of the Multicolinearity Test

\begin{tabular}{lccc}
\hline & PPA & KO & KP \\
\cline { 2 - 2 } PPA & - & & \\
KO & $0,088^{\text {ns }}$ & & \\
KP & $0,378^{*}$ & $0,034^{\text {ns }}$ & - \\
\hline
\end{tabular}

* significant at the $5 \%$ level $(\alpha=0,05)$

ns=not signifiicant

The Kolmogorov-Smirnov based normality test indicates that the four variables used have significance value of more than 0.05 . This makes $\mathrm{H}_{0}$ fail and unacceptable, indicating that the variables used in the study distributed normally.

The Multicolinearity Test. The Multicolinearity test is conducted using a correlation method amongst independent variables. The method is chosen as in the moderate regression analysis with an interaction method the probability of multicolinearity is very high when VIF values are observed as multicolinearity indicators. The criterion showing multicolinearity exists in a correlation method is when the correlation coefficient is $>0.80$ (Gujarati 2003). The results of the multicolinearity test are presented in the Table 5.

The Table 5 suggests that the correlation coefficients amongst variables are less than the maximum limit of 0.80 . This leads one to infer that there is no strong relationship amongst variables; in other words, it complies with multicolinearity.

The Heteroscedasticity Test. The heteroscedasticity test used the scatterplot method. The dependent variable at the $\mathrm{X}$ axis is ZPRED and the dependent variable at the $\mathrm{Y}$ axis is the residual of SRESID. The decision is based on: 
Murwaningsari-The Role of Organizational Commitment and Procedural Justice in Moderating the Relationship ...

Figure 2. Result of Heteroscedasticity Test Using the Scatter Plot Method

Model 1: Heteroscedasticity Test

Scatterplot

Dependent Variable: KM

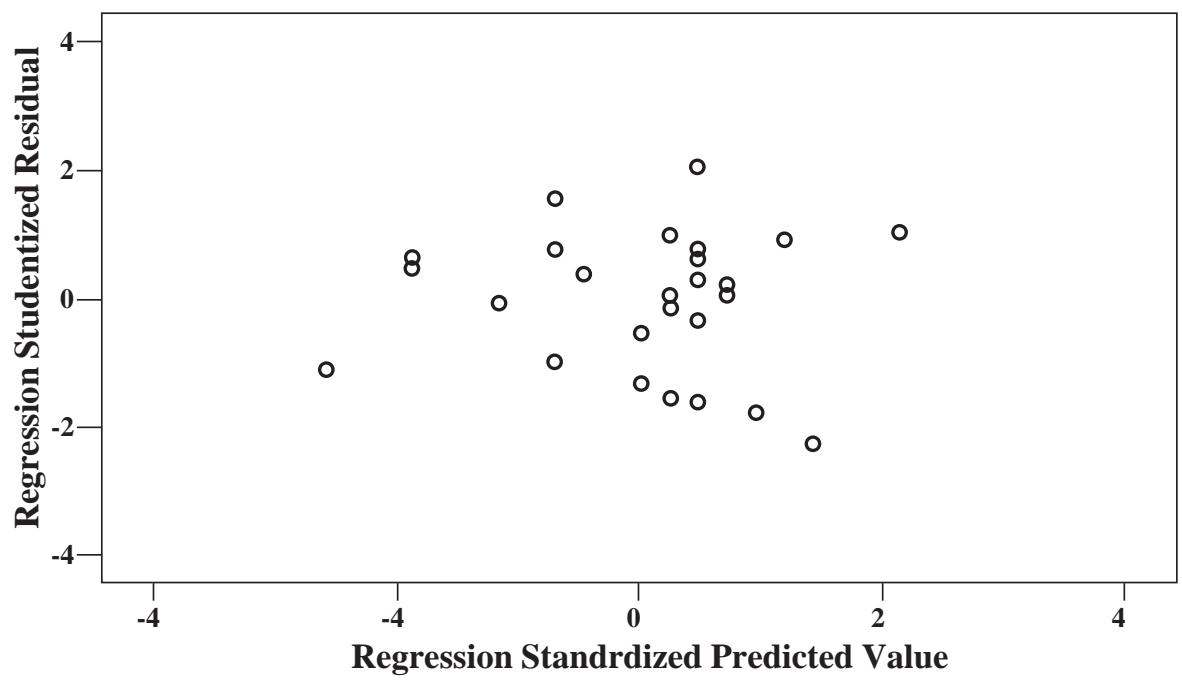

Model 2b: Heteroscedasticity Test

Scatterplot

Dependent Variable: KM

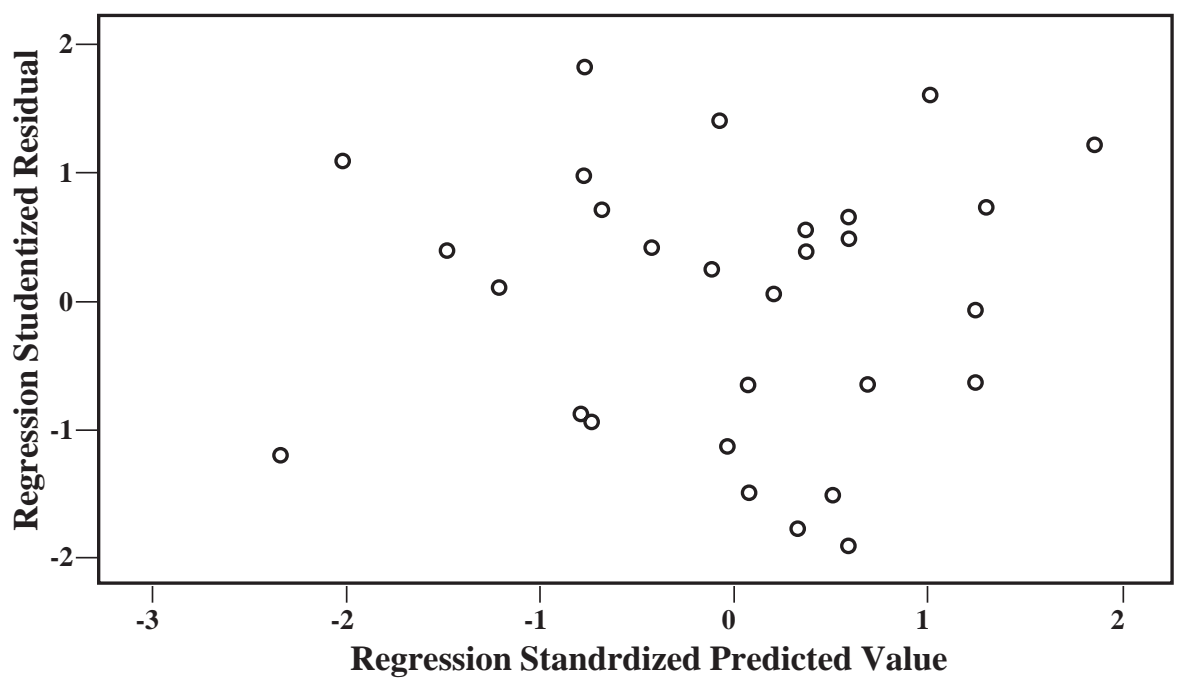


Gadjah Mada International Journal of Business, May - August 2008, Vol. 10, No. 2

Model 3b: Heteroscedasticity Test

Scatterplot

Dependent Variable: KM

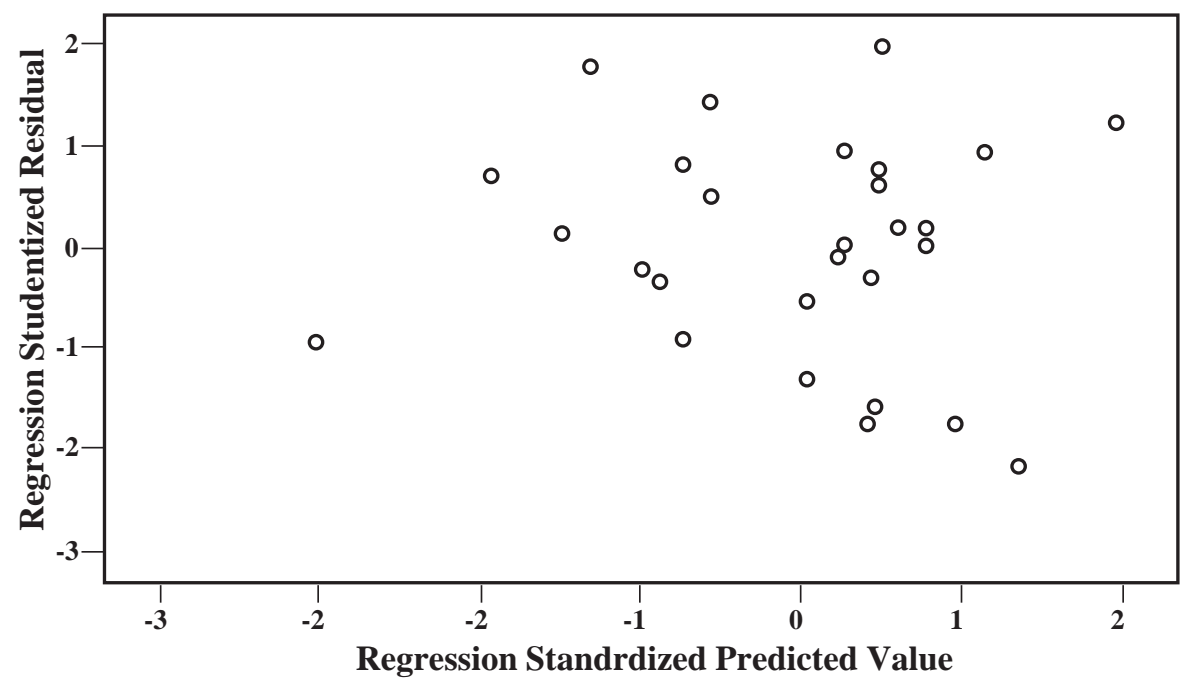

Source: Data processed using SPSS

Table 6. The Heteroscedasticity Results

Sig.

\begin{tabular}{|c|c|c|c|}
\hline Variable & Model 1 & Model 2b & Model 3b \\
\hline РPA0.183 & 0.654 & 0.945 & \\
\hline KO - & 0.842 & - & \\
\hline $\mathrm{KP}-$ & - & 0.729 & \\
\hline $\mathrm{PPA}^{*} \mathrm{KO}$ & - & 0.759 & - \\
\hline PPA*KP & - & - & 0.819 \\
\hline
\end{tabular}

- If there is a certain pattern, say, the below zero at the $\mathrm{Y}$ axis, then the existing dots form a regularly certain pattern (it is wavy, it first widens and then it narrows), then it indicates that the heteroscedasticity has been violated).

- If no clear patterns are found, in that heteroscedasticity assumption is met.

Looking at the scatterplot in the Model 1, it is inferred that the model $2 \mathrm{~b}$ and $3 \mathrm{~b}$ have no heteroscedasticity problems as the scatterplots do not show clear patterns, or it is observable 
Murwaningsari-The Role of Organizational Commitment and Procedural Justice in Moderating the Relationship ...

from the scattered dots above and below zero at the $\mathrm{Y}$ axis.

In addition, the heteroscedasticity test can also be conducted using the Glejser test by regressing each of the independent variables to the absolute residuals as the dependent variables. The Heteroscedasticity hypotheses:

$H_{o}$ : No heteroscedasticity.

$H_{a}$ : Heteroscedasticity exists.

The decision is based on: if sig. < 0.05 , then Ho is rejected (heteroscedasticity exists) and otherwise. The Table 6 shows the heteroscedasticity results.

The Table 6 indicates that the significance of the independent variables Model 1, 2b and 3b is more than 0.05. This makes Ho failed and rejected. As a result, it is inferred that no heteroscedasticity problems exist.

\section{The Autocorrelation Test}

The autocorrelation test was conducted using Durbin Watson. If Durbin Watson values hover around the ceil- ing values $\left(\mathrm{d}_{\mathrm{U}}\right)$, it is expected that there is no autocorrelation.

The autocorrelation hypotheses:

$H_{0}$ : No autocorrelation series.

$H_{a}$ : Autocorrelation series exists.

The results of Durbin Watson estimate are as Table 8 . The Table 8 suggests that:

1. Durbin Watson value for model 1 is of 1.917. Durbin Watson value around $\mathrm{d}_{\mathrm{U}}$ is $\leq \mathrm{d} \leq 4-\mathrm{d}_{\mathrm{U}}$, indicating that Ho fails to be rejected and there is no autocorrelation in the Model 1.

2. Durbin Watson value for the model $2 b$ is of 1.930. Durbin Watson value around $\mathrm{d}_{\mathrm{U}} \leq \mathrm{d} \leq 4-\mathrm{d}_{\mathrm{U}}$, indicating that $\mathrm{H}_{0}$ fails to be rejected and it means that there is no autocorrelation in the Model b2.

3. Durbin Watson value for the model $3 \mathrm{~b}$ is of 1.928. Durbin Watson value around $\mathrm{d}_{\mathrm{U}} \leq \mathrm{d} \leq 4-\mathrm{d}_{\mathrm{U}}$, indicating that $H_{0}$ fails to be rejected and it means that there is no autocorrelation in the model 3b.

Table 7. The Decision Criteria of the Autocorrelation Test

\begin{tabular}{llr}
\hline \multicolumn{1}{c}{ Zero Hypothesis } & \multicolumn{1}{c}{ Decision } & \multicolumn{2}{c}{ Criteria } \\
\hline No positive correlation & Rejected & $0<\mathrm{d}<\mathrm{d}_{\mathrm{L}}$ \\
No positive correlation & No Decision & $\mathrm{d}_{\mathrm{L}} \leq \mathrm{d} \leq \mathrm{d}_{\mathrm{U}}$ \\
No negative autocorrelation & Rejected & $4-\mathrm{d}_{\mathrm{L}}<\mathrm{d}<4$ \\
No negative autocorrelation & No Decision & $4-\mathrm{d}_{\mathrm{U}} \leq \mathrm{d} \leq 4-\mathrm{d}_{\mathrm{L}}$ \\
No autocorrelation $(+) /(-)$ & Failed and Rejected & $\mathrm{d}_{\mathrm{U}}<\mathrm{d}<4-\mathrm{d}_{\mathrm{U}}$ \\
\hline
\end{tabular}


Gadjah Mada International Journal of Business, May - August 2008, Vol. 10, No. 2

Table 8. The Autocorrelation Test

\begin{tabular}{ccccccccc}
\hline Model & $\mathbf{N}$ & $\mathbf{K}^{\prime}$ & $\mathbf{d}_{\mathbf{L}}$ & $\mathbf{d}_{\mathbf{U}}$ & $\mathbf{4 - d}_{\mathbf{U}}$ & $\mathbf{4 - d}_{\mathbf{L}}$ & $\mathbf{D W}$ & Decision \\
\hline 1 & 32 & 1 & 1,373 & 1,502 & 2,498 & 2,627 & 1,917 & No Autocorrelation \\
2b & 32 & 3 & 1,244 & 1,650 & 2,350 & 2,756 & 1,930 & No Autocorrelation \\
$3 \mathrm{~b}$ & 32 & 3 & 1,244 & 1,650 & 2,350 & 2,756 & 1,928 & No Autocorrelation \\
\hline
\end{tabular}

The regression test shows that, as summarized in the Table 9, $p$-value for the PPA variable is of $0.000<$ alpha 0.05 , indicating a rejected Ho1, that is, budgetary participation has a significant effect on managerial performance. The coefficient value is positive $\left(\beta_{1}=\right.$ 0,931 ), suggesting that the higher managerial participation in the budgeting process is, the higher the managerial performance will be. Statistically, this supports the test for the hypothesis 1 at the significance level of 5 percent.

\section{Goodness of Fit (Adj. $R^{2}$ )}

The Table 9 shows the perceived determination coefficient of Adj. $R^{2}$ is of 0.450 . This suggests that the PPA independent variable (Budgetary Participation) is able to explain the variation in the Managerial Performance dependent variable by 45.0 percent, while the remaining variation is explained by other factors not included in the model.

The regression test shows that, as summarized in the Table 10, p-value for the interaction variable of PPA*KO is of $0.078<$ alpha 0.10 . This makes Ho2 rejected, suggesting that organizational commitment has a significant effect on the relationship between budgetary participation and managerial performance. The coefficient is positive $\left(\beta_{3}=0.251\right)$, indicating that the interaction between budgetary participation and organizational commitment increases managerial performance, or in other words the effect of the organizational commitment strengthens the relationship between budgetary participation and managerial performance. Statistically, this supports the test for the hypothesis 2 at the significance level of 10 percent.

To gather evidence of whether organizational commitment enhances the relationship between budgetary participation and managerial performance, however, further tests should be conducted. The moderated regression analysis in the Model 2 resulted in an estimate:

$$
\begin{aligned}
\mathrm{KM}= & 5,353-0,130 \mathrm{PPA}-0,909 \mathrm{KO}+ \\
& \text { 0,251PPA*KO }
\end{aligned}
$$

The total effects of the PPA variable interacting with the $\mathrm{KO}$ variable and substituted from the $\mathrm{KO}$ variable generate this Equation 4.

$\beta_{\text {total }=} \beta_{1}+\beta_{3} \mathrm{KO}$ 
Murwaningsari-The Role of Organizational Commitment and Procedural Justice in Moderating the Relationship ...

Table 9. The Results of the Regression Test for the Hypothesis 1

\begin{tabular}{|c|c|c|c|c|c|}
\hline \multicolumn{6}{|c|}{$K M=\beta_{0}+\beta_{1} P P A+\varepsilon$} \\
\hline \multirow[b]{2}{*}{ Variable } & \multirow[b]{2}{*}{ B } & \multicolumn{3}{|c|}{ t-Test } & \multirow[b]{2}{*}{$\begin{array}{c}\text { F Test } \\
(p \text {-value })\end{array}$} \\
\hline & & t-value & p-value & Adj. $R^{2}$ & \\
\hline (Constant) & 1.628 & 1.977 & 0.057 & & 26.374 \\
\hline PPA & 0.931 & 5.136 & 0.000 & 0.450 & $(0.000)$ \\
\hline
\end{tabular}

Source: Data processed using SPSS

Table 10. The Regression Test Results for the Hypothesis 2

\begin{tabular}{|c|c|c|c|c|c|}
\hline \multirow[b]{2}{*}{ Variable } & \multicolumn{3}{|c|}{ t-Test } & \multirow[b]{2}{*}{ Adj. $R^{2}$} & \multirow[b]{2}{*}{$\begin{array}{c}\text { F Test } \\
\text { (p-value) }\end{array}$} \\
\hline & B & t-value & p-value & & \\
\hline \multicolumn{6}{|c|}{ Model 2a: $K M=\beta_{0}+\beta_{1} P P A+\beta_{2} K O+\varepsilon$} \\
\hline (Constant) & 0.876 & 0.944 & 0.353 & & 15.204 \\
\hline PPA & 0.906 & 5.110 & 0.000 & 0.478 & 0000 \\
\hline $\mathrm{KO}$ & 0.185 & 1.617 & 0.117 & & \\
\hline \multicolumn{6}{|c|}{ Model 2b: $K M=\beta_{0}+\beta_{1} P P A+\beta_{2} K O+\beta_{3} P P A * K O+\varepsilon$} \\
\hline (Constant) & 5,353 & 2.055 & 0.049 & & \\
\hline PPA & -0.130 & -0.096 & 0.827 & 0.517 & 12.073 \\
\hline KO & -0.909 & -1.037 & 0.146 & & $(0.000)$ \\
\hline PPA*KO & 0.251 & 1.535 & 0.078 & & \\
\hline
\end{tabular}

Source: The data are processed using the SPSS 
Gadjah Mada International Journal of Business, May - August 2008, Vol. 10, No. 2

Table 11. The Regression Test Results for Hypothesis 3

\begin{tabular}{|c|c|c|c|c|c|}
\hline \multirow[b]{2}{*}{ Variable } & \multicolumn{4}{|c|}{ t-Test } & \multirow[b]{2}{*}{$\begin{array}{c}\text { F Test } \\
\text { (p-value) }\end{array}$} \\
\hline & $\mathbf{B}$ & t-value & p-value & Adj. $\mathbf{R}^{2}$ & \\
\hline \multicolumn{6}{|c|}{ Model 3a: $K M=\beta_{0}+\beta_{1} P P A+\beta_{2} K P+\varepsilon$} \\
\hline (Constant) & 1.351 & 1.285 & 0.209 & & \\
\hline PPA & 0.899 & 4.527 & 0.000 & 0.435 & 12.925 \\
\hline KP & 0.117 & 0.435 & 0.667 & & $(0.000)$ \\
\hline \multicolumn{6}{|c|}{ Model $3 b: K M=\beta_{0}+\beta_{1} P P A+\beta_{2} K P+\beta_{3} P P A * K P+\varepsilon$} \\
\hline (Constant) & -1.808 & -0.308 & 0.761 & & \\
\hline PPA & 1.597 & 1.235 & 0.227 & 0.421 & 8.508 \\
\hline KP & 1.013 & 0.610 & 0.547 & & $(0.000)$ \\
\hline PPA*KP & -0.197 & -0.547 & 0.589 & & \\
\hline
\end{tabular}

Source: The Data are processed using the SPSS

The regression estimate makes $\beta_{1}=$ $-0,130$ dan $\beta_{3}=0,251$. The KO variable scale ranges from $1-7$. If the $\mathrm{KO}$ is in the scale 1 is $\left(\beta_{2}=1\right)$, the total effect will be of $0.121\left\{\beta_{\text {total }}=-0,130+\right.$ $0,251(1)$. However, if the KO is in the scale 2 , then the total effect is of 0.372 $\left\{\beta_{\text {total }}=-0,130+0,251(2)\right.$. Similarly, if the $\mathrm{KO}$ is in the maximum scale 7 the total effect increases accordingly. This provides evidence that the effect of budgetary participation on managerial performance is higher when organizational commitment increases.

The determination coefficient (Adj. $R^{2}$ ) in the Model 1 is of 0.478 , while Adj. $R^{2}$ in the Model 2 is of 0.517 . This indicates that $A d j . R^{2}$ increases to 0.039 as PPA (Budgetary Participation) interacts with KO (Organizational Commitment) over KM (Managerial Performance).
Table 11 shows that $p$-value for the PPA*KP interaction variable is of $0.589>$ alpha 0.05 , indicating that Ho3 fails and unacceptable - the procedural justice has no significant effect on the relationship between budgetary participation and managerial performance. The coefficient is, however, negative $\left(\beta_{3}=-0,197\right)$; this suggests that the interaction between budgetary participation and procedural justice decreases managerial performance.

The determination coefficient (Adj. $R^{2}$ ) in the model 3a is of 0.432 , while Adj. $R^{2}$ in the model $3 \mathrm{~b}$ is of 0.421 . This suggests that Adj. $R^{2}$ decreases to 0.014 when PPA interacts with KP over the dependent variable, KM. 
Murwaningsari-The Role of Organizational Commitment and Procedural Justice in Moderating the Relationship ...

\section{Conclusion, Limitation, and Directions}

\section{Conclusion}

The results of the three hypotheses tested in the study infer that:

1. Budgetary participation has positive effects on managerial performance, that is, the higher the managers' participation in the budgeting process, the better managerial performance will be. When budgetary objectives and goals are designed and agreed by the management of all levels, this generates employees' personal responsibility to help achieve the objectives as they are involved in the budgeting process (Milani 1975). Greenberg and Folger (1983) argue that budgetary participation increases performance as (i) budgetary participation allows lower management to communicate their thoughts and opinions to the upper management and (ii) budgetary participation allows lower management to choose options, and this involvement makes them committed to and responsible for what they have chosen. This supports Brownell (1982), Brownell and McInnes (1986), Indriantoro (1993), and Hariyanti and Nasir (2002). The hypotesis 1 is therefore supported.

2. The test for the hypothesis 2 shows that organizational commitment serves as the moderating variable. The regression coefficient in the interaction variable (PPA and $\mathrm{KO}$ ) indicates a positive direction, sug- gesting that organizational commitment increases the relationship between budgetary participation and managerial performance. This is consistent with Govindarajan (1986) that used a contingency approach to evaluate various conditional factors affecting the effectiveness of budgetary participation on managerial performance, and one of the conditional factors is organizational. This supports Nouri and Parker (1998), Hariyanti and Nasir (2002), and Sumarno (2005). The Hypothesis 2 is thus supported.

3. The test for the hypothesis 3 does not find evidence that procedural justice is a moderating variable. This suggests that the relationship between budgetary participation and managerial performance is affected by procedural justice. This is derived from the negatively and insignificantly signed coefficients. This finding does not support the previous study by Wasisto and Solihin (2004).

\section{Limitations}

The study, as other empirical studies, has several limitations:

1. The survey method of questionnaire is the only instrument used in the study. The problem that may arise from using this method is the low response rates as compared to the interviewing method or directly involved in a firm's activities. Another limitation is the internal validity, such as the use of self-rating method (Mahoney et al. 1963) in 
Gadjah Mada International Journal of Business, May - August 2008, Vol. 10, No. 2

the managerial performance measurement tends to generate leniency biases.

2. Sample firms are of those firms whose employees are $>100$, suggesting that the results cannot be generalized for firms with employees $<100$.

3. Test instruments: the tests for hypotheses 2 and 3 used the Moderated Regression Analysis with an interaction approach; this generates very high multicolinearity in one (or more) independent variable.

\section{Directions for Future Studies}

The limitations in this study suggest that:

1. Data should be gathered through a survey method as well as interviewing methods or researchers should be directly involved in a firm's activities. The interviewing method is useful to further analyze specific factors related to a firm's activities to increase the firm's operational and financial performance.

2. To analyze the interaction effects amongst independent variables, other test instruments should be employed such as the Moderated Regression Analysis (MRA) method with a (residual) fit approach developed to overcome the multicolinearity problems in the interaction approach. One can also use an MRA method with the Absolute Value.
3. Consistent with Govindarajan (1986) that used the contingency approach to evaluate various conditional factors affecting the affectivity of budgetary participation on managerial performance, the future studies should use an organization's conditional factors other than organizational commitment. Such factors are management accounting or organizational structures observed from delegating control (decentralization or centralization). Other factors are the organization's cultural and individual.

\section{Managerial Implications}

It is hoped that the findings of this study may contribute to the organizational practices in general, primarily those related to the interaction implementation between budgetary participation and conditional factors, i.e. organizations and the interactions between budgetary participation and procedural justice.

Even though the hypothesis 3 does not support the previous studies, the procedural justice is expected to be a factor able to affect the relationship between budgetary participation and managerial performance. Future studies should improve the limitations found in the study. The effects of organizational commitment and procedural justice on the relationship between budgetary participation and managerial performance need to be reexamined to find their consistencies with future studies. 
Murwaningsari-The Role of Organizational Commitment and Procedural Justice in Moderating the Relationship ...

\section{References}

Abdul Rahman, F., and B. Supomo. 2003. Pengaruh partisipasi anggaran dan keterlibatan kerja terhadap senjangan anggaran dengan komitmen organisasi sebagai variabel moderating. Jurnal Bisnis dan Akuntansi 5 (2 August): 127-146.

Angel, H. L., and J. L. Perry. 1981. An empirical assessment of organizational commitment and organizational effectiveness. Administrative Science Quarterly 26: 1-14.

Argyris, C. 1952. The impact of budgets on people. The School of Business and Public Administration. Cornell University

Brownell, P. 1981. Participation in budgeting, locus of control and organizational effectiveness. The Accounting Review 56 (October): 844-860

Brownell, P. 1982. The role of accounting data in performance evaluation, budgetary participation, and organization effectiveness. Journal of Accounting Research 20 (1): 12-27.

Brownell, P., and M. McInnes. 1986. Budgetary participation, motivation and managerial performance. The Accounting Review 61 (4): 587-600.

Brownell, P., and M. Hirst. 1986. Reliance on accounting information, budgetary participation, and task uncertainity: Test of three-way interaction. Journal of Accounting Research 24 (Autumn): 241-251.

Bryan, J. F., and E. A. Locke. 1976. Goal setting as a man of increasing motivation. Journal of Applied Psychology 51: 274-277.

Dunk, A. S. 1993. The effect of budget emphasis and information asymmetry on the relationship between budgetary participation and slack. The Accounting Review.

Dunk, A. S. 1989. Budget emphasis, budgetary participation and managerial performance: A note, accounting. Organizations and Society 14 (4): 321-355.

Early, P. C., and E. A. Lind. 1987. Procedural justice and participation in task selection: The role of control in mediating justice judgment. Journal of Personality and Social Psychology: 1148-1160.

Friedland, N., J. Thibaut, and L. Walker. 1973. Some determinants of the violation of rules. Journal of Applied Social Psychology 3: 103-118.

Ghozali, I. 2001. Aplikasi Analisis Multivariate dengan Program SPSS. Semarang, Indonesia: Badan Penerbit Universitas Diponegoro.

Gordon, L. A., and Millar. 1976. A contingency framework for the design of accounting information system. Accounting, Organizations and Society.

Govindarajan, V. 1986. Impact of parcipation in the budgetary process on managerial attitudes and performance: Universalistic and contingency perspectives. Decision Sciences 17: 496-516.

Greenberg, J., and R. Folger. 1983. Procedural justice, participation and the fair process effect in groups and organization. In Paulus (ed.), Basic Group Process. NJ: Springer-Verlag: 235-256. 
Gadjah Mada International Journal of Business, May - August 2008, Vol. 10, No. 2

Gujarati, D. N. 2003. Basic Econometrics (4 ${ }^{\text {th }}$ ed.). New York: Mc-Graw Hill.

Heneman, H. G. 1974. Comparison of self and superior ratings of managerial performance. Journal of Applied Psychology 59: 638-642.

Hansen, D. R., and M. M. Mowen. 2004. Management Accounting (7 $7^{\text {th }}$ ed.). New York: Thomson, Jakarta: Salemba Empat.

Haryanti, W., and M. Nasir. 2002. Pengaruh partisipasi penyusunan anggaran terhadap kinerja manajerial: Peran kecukupan anggaran dan komitmen organisasi sebagai variabel intervening. SNA.

Hopwood, A. G. 1976. Accounting and Human Behavior. NJ: Prentice Hall.

Indriantoro, N. 1993. The effect of participative budgeting on job performance and job satisfaction with locus of control and cultural dimensions Lexington as moderating variables. Ph.D. Dissertation. Lexington: University of Kentucky.

Kanfer, R, J. Sawyer, P. C. Early, and E. A. Lind. 1987. Participation in task evaluation procedures: The effects of influential opinion expression and knowledge evaluative criteria on attitudes and performances. Social Justice Research.

Kaplan, R. S. 1984. The evolution of management accounting. The Accounting Review.

Kren, L. 1992. Budgetary participation and managerial performance: The impact of information and environmental volatility. The Accounting Review 67.

Lau, C. M., and E. W. Lim. 2002. The intervening effects of participation on the relationship between procedural justice and managerial performance. British Accounting Review 34.

Lawrence, P. R., and J. W. Lorsch. 1967. Differentiation and integration in complex organizations. Administrative Science Quarterly 12: 1-30.

Libby, T. 2001. Referent cognition and budgetary fairness: A research note. Journal of Management Accounting Research 13: 91-105.

Lind, E. A., and T. R. Tyler. 1988. The Social Psychology of Procedural Justice ( $2^{\text {th }}$ ed.): ISBN 0306427265. Springer.

Lindquist, T. M. 1995. Fairness as an antecedent to participative budgeting: Examining the effects of distributive justice. Journal of Management Accounting Research 17:119141.

Locke, E. A. 1967. Motivational effect of knowledge of results: Knowledge or goalsetting? Journal of Applied Psychology 51 (4): 324-329.

Locke, E. A., and G. P. Latham. 1990. Work motivation and satisfaction: Light at the end of the tunnel. Psychological Sciences. 1 (4): 240-246.

Lukka, K. 1988. Budgetary biasing in organization: Theoretical framework and empirical evidence. Accounting, Organization and society 13. New York: John Wiley \& Sons: 281-301.

Merchant, D. 1981. The design of corporate budgeting system: Influence on managerial behavior and performance. The Accounting Review 56: 813-829. 
Murwaningsari-The Role of Organizational Commitment and Procedural Justice in Moderating the Relationship ...

Mahoney, T. A, T. H. Jerdee, and S. J. Carrol. 1963. Development of Managerial Performance: A Research Approach. Cincinnati : South Western Publishing.

McFarlin, D. B., and P. D. Sweeney. 1992. Distributive and procedural justice as predictors of satisfaction with personal and organizational outcomes. Academy of Management Journal 35 (3): 626-637.

Milani, K. 1975. The relationship of participation in budget-setting to industrial supervisor performance and attitudes: A field study. The Accounting Review.

Mowday, R. T. 1979. The measurement of organizational commitment. Journal of Vocational Behavior 14 (2): 224-247.

Murray, D. 1990. The Performance Effects of participative budgeting: An integration of intervening and moderating variables. Behavior Research in Accounting.

Nouri, H., and R. Parker. 1996. The effect of organizational commitment on the relation between budgetary participation and budgetary slack. Behavioral Research in Accounting 8: 76-90.

Nouri, H., and R. Parker. 1998. The relationship between budget participation and job performance: The roles of budget adequacy and organizational commitment. Accounting, Organization and Society 23 (5-6): 467-483.

Poerwati, T. 2002. Pengaruh partisipasi penyusunan anggaran terhadap kinerja manajerial: Budaya organisasi dan motivasi sebagai variabel moderating. Paper presented on Simposium Nasional Akuntansi 5: 737-755.

Riyanto, B. 1997. Strategic uncertainity, management accounting and performance: An empirical investigation of a contingency theory at the firm level. In B. Riyanto (2001) Jurnal Riset Akuntansi, Managemen, Ekonomi 1 (1): 13-32.

Riyanto, B. 1999. The effect of attitude, strategy and decentralization on the effectiveness of budget participation. Jurnal Riset Akuntansi Indonesia 2 (2) (Juli): 136-153.

Shields, J. F., and M. D. Shields. 1998. Antecedents of participate budgeting. Accounting, Organizations and Society 23 (1): 49-76.

Sumarno, J. 2005. Pengaruh komitmen organisasi dan gaya kepemimpinan terhadap hubungan antara partisipasi anggaran dan kinerja manajerial. Paper presented on Simposium Nasional Akuntansi VIII (15-16 September). Solo, Indonesia: 586-606.

Supomo, B. 1998. Pengaruh struktur dan kultur organisasional terhadap efektifitas anggaran partisipatif dalam peningkatan kinerja studi empiris pada perusahaan manufaktur di Indonesia. Thesis unpublished. Yogyakarta, Indonesia: Universitas Gajah Mada Program Pasca Sarjana Magister Sains Akuntansi.

Tang, T. L., and L. J. Sarfield-Baldwin. 1996. Distributive and procedural justice as related to satisfaction and commitment. SAM Advance Management Journal.

Tibaut, J., and L. Walker. 1975. Procedural Justice: A Psychological Analysis. Hillside, NJ: Lawrence Erlbaum. 
Gadjah Mada International Journal of Business, May - August 2008, Vol. 10, No. 2

Van de Ven, and R. Drazin. 1985. The concept of fit in Contingency Theory. In B. Riyanto (2001) Jurnal Riset Akuntansi dan Bisnis. Surabaya, Indonesia.

Wasisto, A., and M. Sholihin. 2004. Peran partisipasi penganggaran dalam hubungan antara keadilan prosedural dengan kinerja manajerial dan kepuasan kerja. Paper presented on Simposium Nasional Akuntansi VII: 565-580.

Wiener, Y. 1982. Commitment in organization: A normative view. Academy of Management Review 7: 418-428

Waterhouse, J. H., and P. Tiessen. 1978. A contingency framework for management accounting system research. Accounting, Organization and Society 3 (1). 